\title{
Status Gastropoda Pada Ekosistem Terumbu Karang Di Pulau Tidung Kepulauan Seribu
}

\author{
Safar Dody ${ }^{1}$, Tjahjo Winanto ${ }^{2}$ \\ ${ }^{1}$ Pusat Penelitian Oseanografi - LIPI, Ancol Jakarta \\ ${ }^{2}$ Fakultas Perikanan dan Ilmu Kelautan Universitas Jenderal Soedirman \\ Email:dodysafar@yahoo.com
}

\begin{abstract}
ABSTRAK
Tujuan penelitian ini adalah untuk mengetahui status struktur komunitas gastropoda pada ekosistem terumbu karang di Pulau Tidung, Kepulauan Seribu. Pengamatan dilakukan pada 2 lokasi terumbu karang berdasarkan kondisi (life form) "rusak" (Stasiun 1: life form 0$24.9 \%$ ) dan kondisi "sedang" (Stasiun 2: life form $\pm 36.05 \%$ ). Pengamatan dilakukan pada daerah terumbu karang menggunakan metode LIT (Line Intercept Transect) sepanjang $50 \mathrm{~m}$ serta pengambilan sampel Gastropoda menggunakan metode transek kuadrat $(1 \mathrm{x} 1 \mathrm{~m})$ pada kedalaman $90 \mathrm{~cm}$. Garis transek (LIT) $50 \mathrm{~m}$ diletakan sejajar dengan garis pantai dengan jarak tiap garis transek adalah $25 \mathrm{~m}$ dengan 3 ulangan. Hasil pengamatan menunjukkan bahwa Gastropoda berasosiasi dengan terumbu karang, karena menggunakan terumbu karang sebagai habitat, tempat berlindung atau memakan jaringan/lendir karang. Jenis-jens yang ditemukan adalah Lambis lambis, Drupella sp., Cypraea tigris, Filifusus filamentosus, Cerithium asper, and Angaria nodosa. Kepadatan Gastropoda adalah 4-7 indv/ $\mathrm{m}^{2}$ (Satasiun $1>$ stasiun 2). Keragaman Gastropoda tergolong sedang $(4.16$ - 36.05\%), dan nilai Dominasi $(\mathrm{D}=0,69)$ oleh jenis Drupella sp.
\end{abstract}

\begin{abstract}
Research was conducted in Tidung Island Thousand Islands. The purpose of research to determine the status and community structure of gastropods on coral reef ecosystems in Tidung Island, Thousand Islands. Determination of observation stations is based on the condition of coral reefs (life form), Station 1: 0 to 24.9\% life form (damaged condition); Station 2: life form $\pm 36.05 \%$ (moderate conditions). Observations of coral reefs life form was conducted used LIT (Line Intercept Transect) along $50 \mathrm{~m}$. Gastropods Sampling was carried out with the quadrant transect method ( $1 \times 1$ $m$ ) at a depth of $90 \mathrm{~cm}$. Transect were placed on top of the 50-meter LIT line parallel to the coastline, the distance between transects $25 \mathrm{~m}$, three repetitions was done in each transect. The results showed that Gastopods are associated with corals, either because they use coral as a habitat, shelter or they feed on the coral tissue/mucus. The species was found that Lambis lambis, Drupella sp., Cypraea tigris, Filifusus filamentosus, Cerithium asper, and Angaria nodosa. Ganstropoda density $4-7$ indv/ ${ }^{2}$ (Station 1 > station 2). Diversity gastropods were moderate (4.16 to 36.05\%), and the gastropods dominancy (D: 0.69) by Drupella sp.
\end{abstract}

Keywords: gastropod; density; diversity; dominancy; coral reefs, the Thousand Islands

\section{Pendahuluan}

Keberadaan gastropoda (moluska) pada ekosistem terumbu karang biasanya karena daerah tersebut merupakan habitat, tempat mencari makan atau makan jaringan karang (Robertson, 1970; Ramesh et al., 1996). Terumbu karang merupakan suatu ekosistem yang sangat kompleks dengan keanekaragaman hayati yang tinggi dan memiliki banyak fungsi ekologis maupun ekonomis (McClanahan, 1989; Ikawati et al., 2001). Beberapa fungsi ekologis terumbu karang antara lain sebagai penyedia nutrient bagi organisme laut, 
melindungi dan menyediakan area asuhan, menyediakan habitat bagi biota laut dan menjaga keseimbangan siklus rantai makanan, dan pelindung fisik dari gelombang (Hallock, 2004). Sedangkan fungsi ekonomis dari terumbu karang yaitu sebagai tempat penangkapan ikan dan biota laut konsumsi, bahan konstruksi dan perhiasan, bahan baku farmasi, dan sebagai daerah wisata dan rekreasi yang menarik.

Salah satu jenis Moluska yang juga menghuni kawasan terumbu karang adalah kelas gastropoda. Gastropoda atau yang lebih dikenal dengan sebutan keong atau siput merupakan salah satu kelas dari Moluska yang memiliki spesies terbanyak. Gastropoda merupakan hewan dasar pemakan detritus (detritus feeder) (Tomascik et al., 1997). Gastropoda adalah salah satu komponen dalam ekosistem laut dengan keanekaragaman yang tinggi, sehingga menyebar luas di berbagai habitat laut. Kelompok hewan bertubuh lunak ini dapat ditemukan mulai dari pinggiran pantai hingga laut dalam. Gastropoda banyak menempati daerah terumbu karang, sebagian dari mereka membenamkan diri di dalam substrat, beberapa dapat dijumpai menempel pada tumbuhan laut seperti mangrove, lamun, dan alga (Kasenda, 2012). Menurut Rizkya (2012) jenis gastropoda yang ditemukan di Kepulauan Seribu antara lain adalah genus Lambis, famili Strombidae dan ordo Mesogastropoda. Keberadaan gastropoda di perairan sangat dipengaruhi oleh kondisi lingkungan. Tujuan dari penelitian ini adalah mengetahui status dan struktur komunitas gastropoda pada ekosistem terumbu karang di Pulau Tidung, Kepulauan Seribu.

\section{Metodologi Penelitian}

Penelitian ini dilaksanakan pada bulan Maret 2015, lokasi penelitian di Pulau Tidung, Kepulauan Seribu, DKI Jakarta. Tahapan kegiatan yang dilakukan meliputi menentukan lokasi, pengambilan sampel, dan pengukuran parameter fisika-kimia air yang meliputi suhu, salinitas, $\mathrm{pH}$, kecerahan dan kedalaman perairan.

\subsection{Menentukan Stasiun}

Penentuan stasiun pengamatan dilakukan berdasarkan kondisi terumbu karang (life form) di lokasi penelitian. Jumlah stasiun pengamatan ditentukan sebanyak 2 titik stasiun, dengan karakteristik stasiun yaitu Stasiun 1: prosentase penutupan karangnya rusak (0-24,9 \%); Stasiun 2: prosentase penutupan karangnya sedang $(36,05 \%)$. Pengamatan life form terumbu karang dilakukan dengan metode LIT (Line Intercept Transect) atau transek garis sepanjang $50 \mathrm{~m}$. (Johan, 2003). Metode ini merupakan metode untuk menghitung luas penutupan karang (life form) dan komunitas biota laut yang berasosiasi dengan terumbu karang.

\subsection{Pengambilan Sampel Gastropoda}

Pengamatan life form terumbu karang dilakukan dengan metode LIT (Line Intercept Transect) atau transek garis sepanjang $50 \mathrm{~m}$. (Loya, 1978). Transek kuadrat pada umumnya digunakan untuk mendapatkan data kualitatif tentang struktur komunitas moluska (gastropoda) di suatu perairan (Brower et al., 1997; Heryanto et al., 2006). Pada survai karang, metode ini biasanya digunakan untuk pengamatan meliputi kondisi biologi, pertumbuhan, tingkat kematian, dan rekruitmen karang di lokasi yang ditandai secara permanen.

Pengambilan sampel gastropoda dilakukan dengan cara mengambil langsung sampel yang berada di dalam transek kuadrat $(1 \times 1 \mathrm{~m})$ pada kedalaman $90 \mathrm{~cm}$. Transek diletakkan di atas garis LIT sepanjang 50 meter sejajar dengan garis pantai, jarak antar transek $25 \mathrm{~m}$, pada tiap-tiap transek dibuat tiga kali pengulangan. Pengambilan sampel pada waktu air laut surut, 
kemudian diamati jenis dan jumlah gastropoda yang berasosiasi dengan terumbu karang. Seluruh biota yang diambil diidentifikasi dengan menggunakan buku identifikasi (Barrett and Yonge, 1985; Dharma, 1988; Jenkins, 2002).

\subsection{Parameter Lingkungan}

Parameter yang akan dibahas dalam penelitian antara lain kepadatan, keanekaragaman, dominansi dan kualitas air.

\section{a. Kepadatan}

Kepadatan adalah jumlah individu per satuan luas area (Brower dan Zar, 1989). Kepadatan individu dapat diketahui dengan penghitungan berikut:

$$
\begin{aligned}
& D i=\frac{n i}{A} \\
& \text { Keterangan : } \quad \text { Di }=\text { Kelimpahan individu jenis ke-i (individu } / \mathrm{m}^{2} \text { ) } \\
& \text { ni = Jumlah individu jenis ke-i } \\
& \mathrm{A}=\text { Luas total area pengambilan sampel }
\end{aligned}
$$

\section{b. Keanekaragaman (Diversity)}

Keanekaragaman jenis disebut juga keheterogenan jenis. Indeks keanekaragaman menunjukkan kekayaan spesies dalam suatu komunitas dan juga memperlihatkan keseimbangan dalam pembagian jumlah per individu per spesies. Indeks keanekaragaman dapat dihitung dengan indeks Shannon Wiener (Odum, 1971) dengan persamaan :

$$
\begin{aligned}
H^{*}=- & \sum P i \ln P i \\
H^{*}==-\sum\left(\frac{n i}{N}\right) \ln \left(\frac{n i}{N}\right) & \text { atau } \\
\text { Keterangan : } & =\text { indeks keanekaragaman } \\
P i & =\text { peluang kepentingan untuk tiap spesies = ni/N } \\
\text { ni } & =\text { jumlah individu spesies ke-i } \\
\mathrm{N} & =\text { jumlah individu total }
\end{aligned}
$$
adalah :

Kriteria hasil keanekaragaman (H') berdasarkan Shannon Wiener (Krebs, 1989a.b)

$$
\begin{array}{ll}
\mathrm{H}^{\prime} \leq 3.32 & : \text { keanekaragaman rendah } \\
3.32<\mathrm{H}^{\prime}<9.97 & : \text { keanekaragaman sedang } \\
\mathrm{H}^{\prime} \geq 9.97 & : \text { keanekaragaman tinggi }
\end{array}
$$

\section{c. Dominansi}

Dominansi spesies tertentu dapat diketahui dengan menggunakan indeks dominansi Simpson (Krebs, 1989a.b) adalah :

$$
\begin{array}{ll}
C=\sum(P i)^{2} & \\
\text { Keterangan : } & \mathrm{C}=\text { indeks dominansi } \\
& \mathrm{Pi}=\text { ni } / \mathrm{N}
\end{array}
$$

Nilai indeks dominansi berkisar antara $0-1$. Nilai indeks dominansi yang mendekati 0 berarti hampir tidak ada dominansi oleh suatu spesies dalam komunitas, dan biasanya diikuti oleh nilai indeks keseragaman yang mendekati 1. Nilai indeks dominansi yang mendekati 1 , 
berarti ada dominansi oleh suatu spesies dalam komunitas tersebut, dengan nilai indeks keseragaman yang semakin rendah atau mendekati 0 (Odum, 1971).

\section{d. Kualitas Air}

Pengukuran parameter kualitas perairan yang meliputi faktor-faktor fisika-kimia perairan yang dapat mempengaruhi pertumbuhan dan kelangsungan hidup gastropoda meliputi suhu, salinitas, pH, kecerahan dan kedalaman perairan (Sorokin, 1993).

Pengukuran parameter fisika dan kimia perairan dilakukan insitu pada setiap stasiun pengamatan, atau sesuai dengan lokasi pengambilan sampel gastropoda.

Hand refraktometer untuk mengukur kadar salinitas suatu perairan. Untuk mengukur suhu dilakukan dengan menggunakan thermometer. Pengukuran $\mathrm{pH}$ dilakukan dengan menggunakan $\mathrm{pH}$ meter. Pengukuran kecerahan air dengan menggunakan secchi disk. Pengukuran kedalaman dapat diukur dengan menggunakan tali berskala.

\subsection{Analisis Data}

Data yang diperoleh di buat tabulasi, lalu di analisis secara deskriptif komperatif untuk membandingkan struktur komunitas gastropoda pada stasiun I dan stasiun II.

\section{Hasil dan Pembahasan}

\subsection{Komposisi Jenis dan Jumlah}

Hasil pengamatan menunjukkan bahwa jumlah individu di stasiun 1 lebih banyak (17 individu) dibandingkan dengan stasiun 2 (6 individu). Sedangkan spesies yang ditemukan di stasiun 1 adalah Drupella sp. (14 individu), Cerithium asper (2 individu), dan Angaria nodosa (1 individu) dan di stasiun 2 yaitu Lambis lambis (1 individu), Cypraea tigris (1 individu), Filifusus filamentosus (1 individu), dan Cerithium asper (3 individu) (Tabel 1). Hasil pengamatan terhadap keberadaan gastropoda pada terumbu karang diduga karena karang merupakan habitatnya, tempat mencari makan atau makan jaringan karang dan berlindung.

Tabel 1. Jumlah gastropoda yang ditemukan di lokasi penelitian

\begin{tabular}{lccc}
\hline \multirow{2}{*}{ Spesies } & \multicolumn{2}{c}{ Jumlah Individu } & \multirow{2}{*}{ Total } \\
\cline { 2 - 3 } & Stasiun 1. & Stasiun 2. & \\
\hline Lambis lambis & 0 & 1 & 1 \\
\hline Drupella sp. & 14 & 0 & 1 \\
\hline Cypraea tigris & 0 & 1 & 1 \\
\hline Filifusus filamentosus & 0 & 1 & 5 \\
\hline Cerithium asper & 2 & 3 & 1 \\
\hline Angaria nodosa & 1 & 0 & \\
\hline Jumlah Individu & 17 & 6 & \\
\hline Jumlah Spesies & 3 & 4 &
\end{tabular}

Stasiun 1 merupakan daerah terumbu karang dengan penutupan karang termasuk dalam kondisi rusak atau berkisar antara 0-24,9 \%. Berdasarkan hasil pengamatan ditemukan jenis spesies gastropoda Drupella sp. dengan jumlah empat belas, Cerithium asper dengan jumlah dua, dan Angaria nodosa dengan jumlah satu. Menurut Lalang et al. (2013) Drupella sp. merupakan salah satu jenis siput laut yang hidup di daerah terumbu karang. 
Berbeda dengan stasiun 2 kondisi luas penutupan karangnya termasuk sedang 36,05 $\%)$. Pada stasiun 2 ditemukan jenis gastropoda Lambis lambis (1 ind), Cypraea tigris (1 ind), Filifusus filamentosus (1 ind), dan Cerithium asper (3 ind). Keberadaan biota ini diduga terkait dengan makanan atau mencari makan di kawasan terumbu karang. Lambis lambis memanfaatkan makroalga yang berada di terumbu karang sebagai salah satu sumber makanannya serta sebagai tempat berlindung (Rizkya et al., 2012).

\subsection{Kepadatan Gastropoda}

Rata-rata kepadatan pada stasiun 1 lebih tinggi jika dibandingkan stasiun 2 dan tingkat kepadatan tertinggi didominasi oleh jenis Drupella sp.(Tabel 2).

Tabel 2. Kepadatan gastropoda di lokasi penelitian

\begin{tabular}{lcc}
\hline \hline \multirow{2}{*}{ Nama Spesies } & \multicolumn{2}{c}{ Kepadatan $\left(\mathbf{I n d} / \mathbf{m}^{\mathbf{2}}\right)$} \\
\cline { 2 - 3 } & Stasiun $\mathbf{~}$ & Stasiun $\mathbf{2}$ \\
\hline Lambis lambis & 0 & 1 \\
\hline Drupella sp. & 5 & 0 \\
\hline Cypraea tigris & 0 & 1 \\
\hline Filifusus filamentosus & 0 & 1 \\
\hline Cerithium asper & 1 & 0 \\
\hline Angaria nodosa & 1 & $\mathbf{4}$ \\
\hline \multicolumn{1}{c}{ Jumlah } & $\mathbf{7}$ & 1 \\
\hline \hline
\end{tabular}

Tingkat kepadatan pada stasiun 1 lebih besar dibandingkan stasiun 2, karena pada stasiun 1 didominasi oleh spesies Drupella sp. dengan jumlah 14 individu. Drupella sp. memakan polip-polip karang sehingga mengakibatkan luas penutupan terumbu karang termasuk kategori rusak dengan presentase bekisar 0-24,9 \%. Hal ini sesuai dengan pernyataan Arbi $(2009 ; 2010)$ bahwa Drupella merupakan jenis keong pemakan polip karang yang cukup penting untuk diketahui keberadaannya di terumbu karang, yaitu sebagai pemangsa karang).

Berdasarkan hasil yang didapat pada kedua stasiun, kepadatan tertinggi terdapat pada jenis spesies Drupella $s p$. sebesar 5 individu $/ \mathrm{m}^{2}$. Jenis ini dikenal sebagai pemakan polip karang dan ditemukan hidup menempel pada karang batu terutama pada jenis karang bercabang (Acropora spp.) (Cappenberg, 2011). Menurut Moyer et al. (1982), selain memakan Acropora spp., Drupella sp. juga ditemukan memakan karang dari jenis dan beberapa jenis karang lainnya. Rendahnya jumlah individu dari jenis-jenis lain yang telah didapat ini diduga disebabkan oleh beberapa hal antara lain habitat yang tidak sesuai, perairan yang keruh akibat sedimentasi yang cukup tinggi, serta keterbatasannya ketersediaan makanan pada suatu ekosistem (Cappenberg, 2011).

\subsection{Keanekaragaman Gastropoda}

Hasil perhitungan menunjukkan bahwa tingkat keanekaragaman pada stasiun 2 ( $\mathrm{H}^{\prime}$ :

4,16) lebih besar dibandingkan stasiun 1 (H': 4,13) (Gambar 1). 


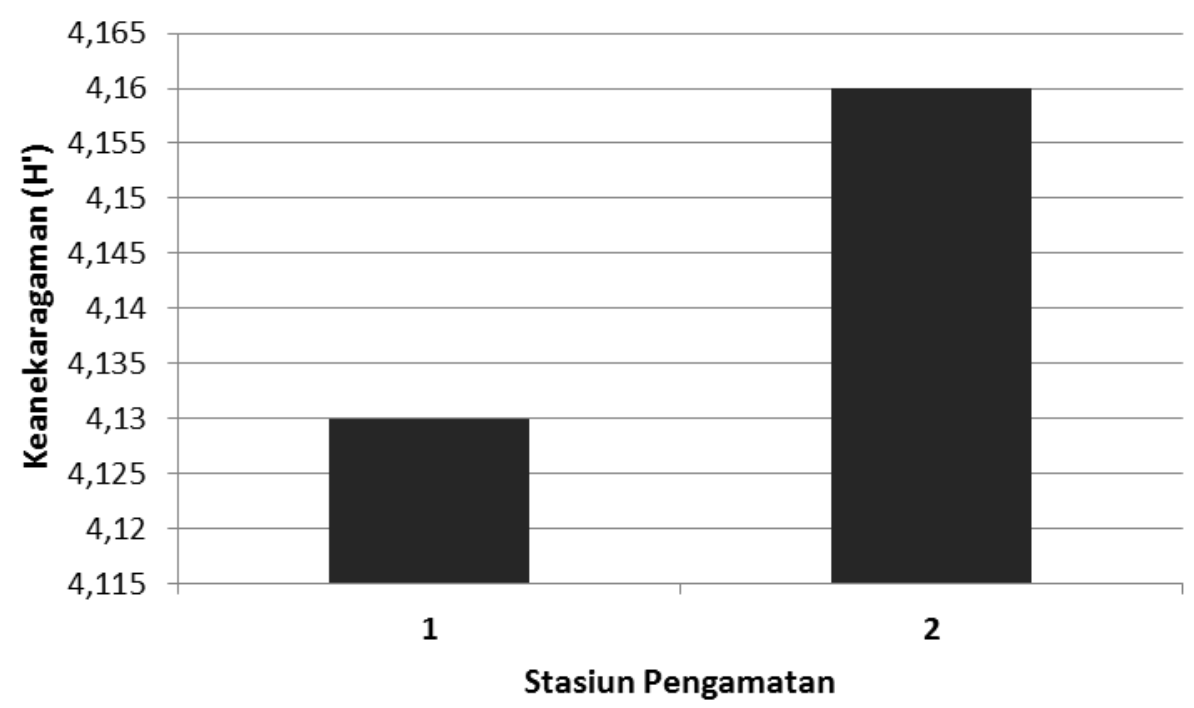

Gambar 1. Rata-rata keanekaragaman (H') gastropoda di P. Tidung

Berdasarkan Shannon Wiener (Krebbs, 1989) nilai keanekaragaman (H') pada stasiun 1 $\left(H^{\prime}: 4,13\right)$ dan pada stasiun 2 (H': 4,13termasuk kategori sedang, karena nilainya diantara $3.32<\mathrm{H}^{\prime}<9.97$. Tingkat keanekaragaman pada stasiun 2 lebih besar dibandingkan stasiun 1 , hal ini mungkin dikarenakan pada stasiun 2 luas penutupan terumbu karangnya termasuk kategori sedang dengan presentase $36,05 \%$, sehingga banyak gastropoda yang mengunjungi terumbu karang untuk mencari makan dan mencari tempat perlindungan. Seperti pernyataan Radiarta et al. (1999) daerah terumbu karang dimanfaatkan oleh kebanyakan organisme penghuni karang tersebut sebagai tempat untuk mencari makan, sebagai daerah perkembangan, sebagai tempat asuhan, sebagai daerah perlindungan, serta tempat pemijahan bagi biota-biota laut. Sedangkan pada stasiun 1 tingkat keanekaragamannya lebih sedikit dikarenakan pada stasiun 1 didominansi oleh Drupella sp. yang memakan polip-polip karang.

Tinggi rendahnya nilai indeks keanekaragaman jenis dapat disebabkan oleh berbagai faktor. Faktor tersebut antara lain jumlah jenis atau individu yang didapat, adanya beberapa jenis yang ditemukan dalam jumlah yang lebih melimpah daripada jenis lainnya, kondisi homogenitas substrat, kondisi habitat (Arbi, 2010).

\subsection{Dominansi}

Hasil penghitungan menunjukkan bahwa nilai dominansi pada stasiun $1(0,697)$ lebih tinggi dibanding stasiun $2(0,334)$ (Gambar 2). 


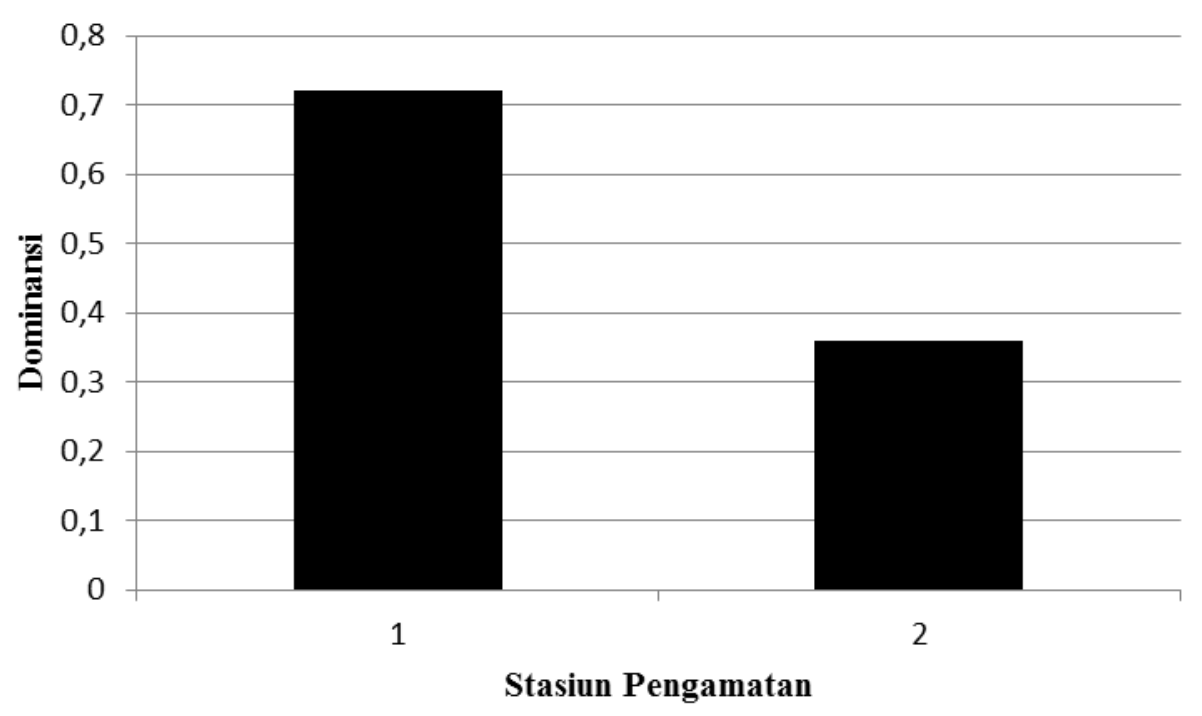

Gambar 2. Rata-rata dominansi gastropoda di P. Tidung

Nilai dominasi berkisar antara 0 - 1 nilai yang terbesar terdapat pada Stasiun 1, dimana pada stasiun ini didominanasi oleh spesies Drupella sp. Nilai terkecil terdapat pada stasiun 2. Dimana pada stasiun 2 didapatkan spesies Lambis lambis, Cypraea tigris, Filifusus filamentosus, dan Cerithium asper dengan jumlah yang sama sehingga tidak ada yang mendominansi. Semakin besar nilai indeks, maka semakin besar adanya kecenderungan salah satu spesies yang mendominasi populasi. Nilai indeks dominansi yang mendekati 1, berarti ada dominansi oleh suatu spesies dalam komunitas tersebut, dengan nilai indeks keseragaman yang semakin rendah atau mendekati 0 (Odum, 1971).

\subsection{Status Gastropoda Pada Terumbu Karang}

Terumbu karang adalah salah satu ekosistem di laut yang sangat penting. Perairan terumbu karang banyak dimanfaatkan oleh organisme penghuni terumbu karang sebagai daerah penyedia makanan, daerah perkembangan, daerah asuhan, dan daerah perlindungan (Radiarta et al. 1999).

Gastropoda jenis spesies Drupella sp. memanfaatkan terumbu karang sebagai makanannya. Drupella sp. adalah salah satu jenis siput laut yang memakan polip karang. Pemangsaan dalam jumlah yang besar akan mengakibatkan kerusakan terumbu karang, siput ini menempel pada karang untuk memakan polip karang dan meninggalkan bekas berwarna putih yang disebut skars (Modica and Holford, 2010). Hal itu sesuai dengan hasil yang didapat pada stasiun satu dengan kondisi terumbu karang yang rusak. Terumbu karang sebagai tempat mencari makan bagi organisme Drupella sp. sehingga terjadi hubungan parasitisme, dimana Drupella sp. mendapatkan keuntungan karena memperoleh makanan dan terumbu karang mengalami kerugian atau kerusakan akibat dari pemangsaannya. Menurut Barco et al. (2010), apabila pemangsaan terjadi dalam waktu yang lama dan populasi Drupella sp. yang banyak dikhawatirkan akan merusak terumbu karang dengan cakupan area yang lebih luas. Drupella $s p$. tumbuh dan berkembang di daerah tertumbu karang agar terlindungi dari serangan predator dan pada saat yang sama menjadi pemangsa polip karang (Morton and Blackmore, 2009). Seiring dengan menurunnya kesehatan terumbu karang, maka aktivitas pemangsaan oleh Drupella akan semakin meningkat. Menurut Jimenez et al. (2012), akibatnya pada daerah tersebut populasi Drupella juga bertambah banyak, sehingga berpengaruh terhadap kondisi terumbu karang pada Pulau tersebut. Kerusakan terumbu 
karang yang terjadi pada perairan tersebut tidak hanya disebabkan oleh kehadiran Drupella $s p$. sebagai organisme parasit yang memangsa polip karang (Miller and Dolman, 2008), tetapi juga di pengaruhi oleh aktivitas manusia di daratan seperti buangan limbah rumah tangga kedalam perairan sehingga mempengaruhi faktor fisik dan kimia di peraian dan kegiatan pariwisata yang ada di perairan setempat.

Spesies Lambis lambis, Cypraea tigris, Cerithium asper, Filifusus filamentosus dan Angaria nodosa yang berada pada terumbu karang diduga memanfaatkan ekosistem terumbu karang tersebut untuk mencari makan, berlindung dari predator, dan tempat pengasuhan. Sesuai dengan pernyataan Radiarta et al. (1999) bahwa perairan terumbu karang banyak dimanfaatkan oleh organisme penghuni terumbu karang sebagai daerah penyedia makanan, daerah perkembangan, daerah asuhan, dan daerah perlindungan. Terjadinya asosiasi antara spesies tersebut dengan terumbu karang, karena ada simbiosis mutualisme atau saling menguntungkan, dimana gastropoda tersebut memperoleh makanan dari makroalga yang menempel pada terumbu karang. Menurut Rizkya et al., (2012) gastropoda memanfaatkan makroalga sebagai salah satu sumber makanannya, serta sebagai tempat berlindung. Sedangkan terumbu karang terhindar dari epifit yang menghalangi terumbu karang untuk bertahan hidup terutama dalam perebutan nutrient, fotosintesis, dan perebutan lahan substrat.

\subsection{Parameter Kualitas Air}

Berdasarkan pengamatan pada stasiun 1 dan 2 nilai parameter kualitas perairan yang didapat meliputi suhu, salinitas, $\mathrm{pH}$, dan kecerahan menunjukkan pada kisaran yang dapat ditoleransi baik oleh gastropoda maupun terumbu karang. (Tabel 4).

Tabel 4. Parameter kualitas air di P. Tidung.

\begin{tabular}{lccc}
\hline \multirow{2}{*}{ Parameter } & \multicolumn{2}{c}{ Hasil } & \multirow{2}{*}{ Toleransi Kisaran } \\
\cline { 2 - 3 } & Stasiun 1. & Stasiun 2. & \\
\hline Suhu & $29^{\circ} \mathrm{C}$ & $28^{\circ} \mathrm{C}$ & $18-30^{\circ} \mathrm{C}$ (Gosling, 2003) \\
\hline Salinitas & $29 \%$ \% & $29 \% 0$ & $26-32 \%$ (Gosling, 2003) \\
\hline $\mathrm{pH}$ & 8 & 8 & $6,5-8,5$ (Gosling, 2003) \\
\hline Kecerahan & $90 \mathrm{~cm}$ & $90 \mathrm{~cm}$ & - \\
\hline \hline
\end{tabular}

Suhu yang diamati berkisar antara $28-29{ }^{\circ} \mathrm{C}$, suhu dengan kisaran tersebut masih tergolong normal dan sesuai sebagai syarat hidup terumbu karang dan gastropoda. Hal yang sama dikemukakan oleh Nontji (1987), bahwa suhu $28-29^{\circ} \mathrm{C}$ merupakan kisaran suhu yang baik untuk pertumbuhan (life form), karena terumbu karang dapat hidup dengan baik pada kisaran suhu antara $25-30^{\circ} \mathrm{C}$. Gosling (2003) juga menambahkan bahwa perkembangan normal bivalvia gastropoda pada kisaran suhu antara $18-30^{\circ} \mathrm{C}$, sedangkan suhu untuk pertumbuhan optimum adalah $24-30^{\circ} \mathrm{C}$, dimana suhu tersebut berpengaruh terhadap metabolisme. Sedangkan Drupella dapat hidup dan berkembang biak pada kisaran suhu 28$31^{\circ} \mathrm{C}$ (Lalang et al. 2013). Robert et al., (1982); Robert (2010) juga menyampaikan bahwa suhu optimal beberapa jenis Mollusca sekitar $20^{\circ} \mathrm{C}$ dan apabila melampaui batas tersebut akan mengakibatkan penurunan aktivitas kehidupannya.

Salinitas yang diamati sekitar $29 \%$, salinitas tersebut masih berada pada kisaran toleransi gastropoda. Salinitas tersebut juga masih layak untuk pertumbuhan karang maupun organisme lainnya, sesuai dengan pernyataan Sadarun et al., (2006); Sadarun (2006) bahwa salinitas optimum bagi kehidupan karang berkisar antara 30-35 \%o. Sedangkan salinitas optimum untuk gastropoda berkisar antara 26-32 \% Gosling (2003). Drupella dapat hidup dan berkembang biak dengan kisaran salinitas 30-32 \%o (Lalang et al., 2013). 
$\mathrm{pH}$ air yang diamati sekitar 8. pH pada perairan ini masih dalam kondisi normal dan masih berada pada kondisi yang dapat ditoleransi oleh gastropoda. Umumnya $\mathrm{pH}$ air laut relatif stabil dengan kisaran antara 7,5-8,4. Menurut Gosling (2003) batasan pH yang ideal untuk biota laut berkisar antara 6,5-8,5 dan $\mathrm{pH}$ yang sesuai untuk kehidupan mollusca berkisar antara 5,7-8,4.

Kecerahan air di lokasi penelitian sekitar $90 \mathrm{~cm}$, sehingga penetrasi cahaya masih dapat menembus dasar perairan. Hal ini menunjukkan tingkat kecerahan yang baik untuk pertumbuhan terumbu karang. Sinar matahari dibutuhkan oleh Zooxanthellae untuk berfotosintesis dimana hewan karang mendapat nutrisi dari hasil fotosintesis. Hal ini sesuai dengan pernyataan Ikawati et al. (2001); Veron (1993) bahwa kondisi tersebut menunjukkan intensitas cahaya yang tinggi dan dapat mendukung proses fotosintesis zooxanthellae yang secara langsung akan mempengaruhi pertumbuhan karang (life form) dan kemampuan karang untuk menghasilkan kalsium karbonat $(\mathrm{CaCO} 3)$ serta pembentukan terumbu karang akan selalu optimal. Supriharyono (2007) juga menyatakan bahwa tanpa cahaya yang cukup yang masuk dalam badan air laju fotosintesis akan berkurang.

\section{Kesimpulan}

Berdasarkan hasil hasil penelitian yang dilakukan di Pulau Tidung, Kepulauan Seribu dapat disimpulkan bahwa:

1. Gastropoda berada pada ekosistem terumbu karang karena merupakan habitatnya, sedang mencari makan dan tempat berlindung. Jenis yang ditemukan yaitu Lambis lambis, Drupella sp., Cypraea tigris, filifusus filamentosus, Cerithium asper, dan Angaria nodosa.

2. Tingkat kepadatan ganstropoda 4-7 indv/ $/ \mathrm{m}^{2}$ (stasiun $1>$ stasiun 2). Keanekaragaman gastropoda tergolong sedang $(4,16-36,05 \%)$, dan jenis gastropoda yang mendominansi 0,69) adalah Drupella sp.

\section{DAFTAR PUSTAKA}

Arbi, U.Y. 2009. Drupella (Siput Pemakan Karang Drupella) Jurnal Oseana, 3:19-24

Arbi, U.Y. 2010. Moluska di Pesisir Barat Perairan Selat Lembeh, Kota Bitung, Sulawesi Utara. UPT Loka Konservasi Biota Laut Bitung, Pusat Penelitian Oseanografi. LIPI. Jurnal Bumi Lestari. Vol 10: 60-68.

Barrett, J and Yonge, C.M. 1985. Collins Pocket Guide to The Sea Shore. Collins 8 Grafton Street, London W1. 272p.

Barco A, Claremont M, Reid D.G, Houart R, Bouchet P, Williams S.T, Cruaud C, Couloux A, and Oliverio M. 2010. A molecular phylogenetic framework for the Muricidae, a diverse family of carnivorous gastropods. Mol Phylogenet Evol 56:1025-1039. Edward Arnold (Publiser). London.

Brower, J.E. and Zar, J.H. 1997. Field and Laboratory Method forGeneral Ecology Wm. C. Brown Company Publisher. America p.301.

Brower, J.E. and Zar, J.H. 1989. Field and Laboratory Methods for General Ecology. W. M. Brown Company Publ. Dubuque Lowa.

Buddemeier, R.W., Kleypas, J.A., and Aronson, R.B. 2004. Coral Reefs and Global Climate Change: Potential Contributions of Climate Change to Stresses on Coral Reef Ecosystems. Pew Center on Global Climate Change.

Cappenberg, H.A.W. 2011. Kelimpahan dan Keanekaragamaan Megabenthos di Perairan Teluk Ambon. Oseanologi dan Limnologi di Indonesia. 37(2): 277-294. 
Cappenberg, H.A.W., dan Panggabean, M.G.I. 2005. Moluska di Perairan Terumbu Gugus Pulau Pari, Kepulauan Seribu, Teluk Jakarta. Oseanologi dan Limnologi di Indonesia 37:69-80.

Dharma, B. 1988. Siput dan Kerang Indonesia I. PT. Sarana Graha, Jakarta. : 111 hal.

Gosling E. 2003. Bivalve Molluscs. Biology, Ecology and Culture. Fishing News Books. Blackwell science. 443p.

Hallock, P. 2004. Evolution And Function Of Coral Reef Ecosystems. Earth System: History And Natural Variability - Vol. IV

Heryanto, R., Marsetiowati dan Yulianda, F. 2006. Metode Survei dan Pemantauan Populasi Satwa seri kelima: Siput dan Kerang. Bidang Zoologi P2B - LIPI: 56 pp.

Ikawati, Y., Hanggarawati, P.S., Parlan, H., Handini, H., dan Siswodiharjo, B. 2001. Terumbu Karang di Indonesia. MAPITEK bekerjasama dengan Kantor Menteri Negara Riset dan Teknologi. Jakarta.198 hal.

Jenkins, B. 2002. Learning Mollusca Trough Latest Portfolio of Theory and Practical. Dominant Publisher and Distributors. New Delhi-110002. 319p.

Jimenez , H., Dumas, P., Ponton, D., and Ferraris, J. 2012. Predicting invertebrate assemblage composition from harvesting pressure and environmental characteristics on tropical reef flats. Coral Reefs 31:89-100.

Johan, O. 2003. Metode Survei Terumbu Karang Indonesia. Yayasan Terangi. Jakarta, 98 hal.

Kasenda, P. 2012. Sea Marine Education Siput Gastropoda yang Menempel pada Alga Makro. http://petros- kasenda.blogspot.com/2012/03/siput-gastropoda yang-menempelpada.html.

Krebbs, C.J. 1989.a. Ecological Methodology. Harper Collin Publishing, Canada.

Krebs, C.J. 1989.b. Ecology The Experimental Analysis of Distribution and Abundance 3nd edition. Harper and Row Publisers. New York. 776 pp.

Lalang, Sadarun, B., Haya, M.Y. 2013. Kelimpahan Drupella dan Kondisi Terumbu Karang di Perairan Pulau Mandike Selat Tiworo Kabupaten Muna, Sulawesi Tenggara. Jurnal Mina Laut Indonesia. Vol. 1: 12-22.

Loya, Y. 1978. Plotless and Transect Methods In: Stoddard, D.R., and R.E. Johannes, Coral Reef Research Methods, Paris (UNESCO): 22-32.

McClanahan, T.R. 1989. Kenyan coral reef-associated gastropod fauna: a comparison between protected and unprotected reefs. Marine Ecology Progress Series. Mar. Ecol. Prog. Ser. Vol. 53: 11-20.

Miller I, and Dolman A. 2008. Relative role of disease and predators asdrivers of decline in coral cover on the Great Barrier Reef. Proc 11th Int Coral Reef Symp 6:216-220.

Modica M.V, and Holford M. 2010. The Neogastropoda: evolutionary innovations of predatory marine with remarkable in pharmacological potential. In: Pontarotti P (ed) Evolutionary biology: concepts, molecular and morphological evolution. SpringerVerlag, Berlin, pp 249-270.

Morton, B, and Blackmore, G. 2009. Seasonal variations in the density of and corallivory by Drupella rugosa and species Cronia margariticola (Caenogastropoda: Muricidae) from the coastal waters of HongKong: ('plagues' or 'aggregations')? J Mar Biol Assoc U K 89: $147-159$.

Moyer, J.T., Emerson, W.K., and Ross, M. 1982. Massive destruction of scleractinian corals by the muricid gastropod, Drupella, in Japan and the Philippines. Nautilus, 96: 69-82.

Nontji, A., 1987. Laut Nusantara. Djambatan. Jakarta. 300 hal.

Odum, E.P. 1971. Fundamental of Ecology. W.E. Saunders, Philadelphia: 574 pp. 


\section{JURNAL IlMU Kelautan KePUlaUAN, 1 (2) ; 11-21, DeSEMBER 2018}

Radiarta, I.N., Dahuri, R., Zairion, 1999. Kondisi Ekosistem Terumbu Karang di Perairan Barat Daya Sumbawa, Nusa Tenggara Barat. Jurnal Penelitian Perikanan Indonesia, 5 (2): 87-9 5.

Ramesh, D.A., Jeyabaskaran, R and Pandian, L.P. 1996. Gastropods and Bivalves Associated With Reef Building Corals, Palk Bay, Southeastern India. Phuket Marine Biological Center Special Publication 16: 257-260.

Rizkya, S., Rudianti, S., dan Muskananfola, M.R. 2012. Studi Kelimpahan Gastropoda (Lambis spp.) Pada Daerah Makroalga di Pulau Pramuka, Kepulauan Seribu. Vol 1:17. Tersedia: http://ejournal-s1.undip.ac.id/index.php/maquares.

Robertson, R. 1970. Review of the preda tors and parasites of stony corals with special reference to symbiotic prosobranch gastropods. - Pacific Science 24: 43-54.

Robert, D., Soemodihardjo, S., and Kastoro, W. 1982. Shallow Water Marine Molluscs of North-West Java. Lembaga Oseanologi Nasional-LIPI, Jakarta: 143 pp.

Robert, P., 2010. When Parasites Become Prey : Ecological and Epidemiological Significance of Eating Parasites. Review. Department Of Zoologi, University of Otago, PO Box 56, Dunedin 9054, New Zealand. p31.

Sadarun, B., Nezon, E., Wardono, S., Afandy, Y.A., dan Nuriadi, L. 2006. Petunjuk Pelaksanaan Transplantasi Karang. Departemen Kelautan dan Perikanan. Jakarta 36 hal.

Sadarun. 2006. Pedoman Pelaksanaan Transplantasi Karang. Direktorat Konservasi dan Taman Nasional Laut dan Direktorat Jendral KP3K. DKP. Jakarta. 36 hal.

Sorokin Y.I. 1993. Coral Reef Ecology. New York: Springer - Verlag Berlin Heidelberg. Germany.

Supriharyono. 2007. Pengelolaan Ekosistem Terumbu Karang. Djambatan. Jakarta, 129 hal.

Tomascik, T., Mah, A.J., Nontji, A., and Moosa, M.K. 1997. The Ecology of Indonesian Seas (Part II). Hongkong: Periplus Editions (HK) Ltd.

Veron, J.E.N. 1993. Corals of Australia and the Indo-Facific. Honolulu:University of Hawaii Press. 